\title{
Increases in plasma lysosomal enzymes in Type 1 (insulin-dependent) diabetes mellitus: relationship to diabetic complications and glycaemic control
}

\author{
P.J.Waters ${ }^{1}$, M.D.Flynn ${ }^{2}$, R.J.M.Corrall ${ }^{2}$ and C. A.Pennock ${ }^{1}$ \\ ${ }^{1}$ Department of Chemical Pathology, St. Michael's Hospital, and 2 Department of Diabetes and Endocrinology, Bristol Royal Infirmary, \\ Bristol, UK
}

\begin{abstract}
Summary. Lysosomall enzymes degrade membrane glycoconjugates, and increased circulating enzyme activity may be an important mechanism in the pathogenesis of diabetic microangiopathy. We have assayed a profile of seven lysosomal enzyme activities $\left(\mathrm{nmol} \cdot \mathrm{h}^{-1} \cdot \mathrm{ml}^{-1}\right)$ in platelet-free plasma from 54 Type 1 (insulin-dependent) diabetic subjects (median age 31 years) and 42 matched normal control subjects. A significant increase in median (interquartile range) enzyme activity was measured in diabetic compared to control subjects for $\beta$-D-glucuronidase, $121(97.7-171)$ vs $88.8(62.8-113), \quad p<0.001 ; \quad \beta$-D-Nacetylglucosaminidase, 693 (568-799) vs 568 (462-686), $p<0.001 ; \alpha$-D-mannosidase, $23.8(16.7-28.9)$ vs $14.5(10.1-20.0), p<0.001$; and $\beta$-D-galactosidase, 6.94 (6.11-9.99) vs $6.66(4.78-8.33), p<0.04$. In contrast, $\alpha$-L-fucosidase, $\alpha$-D-galactosidase and $\beta$-D-mannosidase activities were similar in diabetic and control subjects. None of the enzyme activities differed significantly $(p<0.05)$
\end{abstract}

between 24 diabetic patients with clinical complications and 30 complication-free diabetic patients with similar glycaemic control which does not support the hypothesis that enzyme increases in diabetes arise simply by leakage from damaged tissues. In the diabetic subjects $\mathrm{HbA}_{1}$, median (interquartile range) $9.10(7.40-10.60)$, was significantly related to $\beta$-D-glucuronidase $\left(r_{\mathrm{s}}=0.56, p<0.001\right)$ and $\beta$-D-Nacetylglucosaminidase $\left(r_{\mathrm{s}}=0.55, p<0.001\right)$. We have therefore demonstrated in diabetic subjects an increase in certain lysosomal glycosidases, that correlates with glycaemic control. Such increased enzyme activities acting on endothelial and basement membrane substrates may reduce glycoconjugate content, modify charge density, and thereby influence membrane permeability, a hallmark of microangiopathy.

Key words: Lysosomal enzymes, glycosidases, diabetes mellitus, microangiopathy, hyperglycaemia.
Lysosomal glycosidases are widely distributed in tissues and circulating blood cells. They are responsible for intracellular breakdown of complex macromolecules (glycoproteins, glycolipids and glycosaminoglycans) [1] and may also act extracellularly to degrade endothelial membrane glycoconjugates [2, 3]. Their presence in plasma, together with specific receptors on most cell surfaces, implies that cellular secretion and uptake of lysosomal enzymes is a normal physiological process [4].

Structural and functional abnormalities of membranes are recognised features of diabetes mellitus. These may be related to known abnormalities in membrane glycoconjugate content $[5,6]$. Circulating lysosomal glycosidases may mediate such membrane damage and thus be implicated in the pathogenesis of diabetic vascular complications.

Increased circulating activities of one or more lysosomal enzymes are reported in diabetic subjects [7] but their relationship to metabolic control and to diabetic complications is contentious. A serious criticism of previous studies is their use of serum rather than plasma. In vitro enzyme release from platelets during clotting leads to far higher lysosomal enzyme activities in serum than are found in plasma [8]. Platelets from diabetic patients show an increased tendency to aggregation in vitro [9], which may further exaggerate serum enzyme levels. Assay of plasma, not serum, is therefore essential to assess the in vivo significance of diabetic changes in circulating enzymes. We have assayed a profile of seven lysosomal enzymes in platelet-free plasma from diabetic patients and control subjects. These seven enzymes were chosen to represent a cross-section of the enzymes involved in glycoconjugate catabolism, including enzymes acting on glycoproteins, glycolipids and glycosaminoglycans. The aim of this study was to determine their relationship to diabetic complications and glycaemic control. 
Table 1. Assay conditions for plasma lysosomal enzymes

\begin{tabular}{|c|c|c|c|}
\hline Enzyme & $\begin{array}{l}\text { Substrate } \\
\text { concentration } \\
(\mathrm{mmol} / \mathrm{l})\end{array}$ & Buffer & $\begin{array}{l}\text { Incubation } \\
\text { time } \\
\text { (min) }\end{array}$ \\
\hline $\begin{array}{l}\beta \text {-D-glucuronidase } \\
\beta \text {-D-Nacetyl- }\end{array}$ & 10.0 & $\mathrm{Ac}^{\mathrm{a}} \mathrm{pH} 4.0$ & 30 \\
\hline glucosaminidase & 2.0 & $\mathrm{MV}^{b} \mathrm{pH} 4.4$ & 15 \\
\hline$\alpha$-D-mannosidase & 1.0 & MV pH 3.5 & 30 \\
\hline$\beta$-D-galactosidase & 0.5 & $\mathrm{MV} \mathrm{pH} 4.2^{\mathrm{c}}$ & 30 \\
\hline$\beta$-D-mannosidase & 2.0 & MV pH 3.2 & 30 \\
\hline$\alpha$-D-galactosidase & 10.0 & $\mathrm{MV} \mathrm{pH} 4.5$ & 30 \\
\hline$\alpha$-L-fucosidase & 0.5 & MV pH 5.0 & 30 \\
\hline
\end{tabular}

${ }^{a}$ Ac, $0.1 \mathrm{~mol} / 1$ acetic acid/sodium acetate;

${ }^{b} \mathrm{MV}, \mathrm{Mcllvaine}$ 's buffer. This is prepared by mixing $0.1 \mathrm{~mol} / \mathrm{l}$ citric acid and $0.2 \mathrm{~mol} / \mathrm{l}$ di-sodium hydrogen orthophosphate;

c $100 \mathrm{mmol} / \mathrm{l}$ sodium chloride was also incorporated in this buffer (for $\beta$-D-galactosidase assay only)

Table 2. Plasma lysosomal enzyme activities and parameters of glycaemic control: comparison of Type 1 (insulin-dependent) diabetic patients with and without clinical complications

\begin{tabular}{lll}
\hline & $\begin{array}{l}\text { Patients with- } \\
\text { out complica- } \\
\text { tions } \\
(n=30)\end{array}$ & $\begin{array}{l}\text { Patients with } \\
\text { complications } \\
(n=24)\end{array}$ \\
\hline$\beta$-D-glucuronidase & $127(97.4-164)$ & $120(97.7-178)$ \\
$\beta$-D-Nacetylglucosaminidase & $675(532-799)$ & $728(595-813)$ \\
$\alpha$-D-mannosidase & $24.4(18.9-28.9)$ & $21.0(16.2-29.3)$ \\
$\beta$-D-galactosidase & $6.66(5.55-9.41)$ & $8.19(6.66-10.2)$ \\
$\beta$-D-mannosidase & $230(195-288)$ & $206(170-268)$ \\
$\alpha$-D-galactosidase & $12.8(10.5-13.9)$ & $12.8(10.4-15.5)$ \\
$\alpha$-L-fucosidase & $551(330-661)$ & $497(330-602)$ \\
HbA $(\%)$ & $9.05(7.80-9.90)$ & $9.10(7.35-10.7)$ \\
Fructosamine $(m m o 1 / 1)$ & $2.85(2.70-3.20)$ & $3.10(2.80-3.25)$ \\
Glucose $(m m o l / 1)$ & $15.4(10.1-18.2)$ & $12.3(9.8-17.6)$ \\
\hline
\end{tabular}

$p=$ NS for all comparisons.

All plasma enzyme activities are given in $\mathrm{nmol} \cdot \mathrm{h}^{-1} \cdot \mathrm{ml}^{-1}$. All data are expressed as median (interquartile range)

\section{Subjects and methods}

\section{Patients}

We studied 54 Type 1 (insulin-dependent) diabetic subjects with and without clinical complications ( 35 male, 19 female; median age 31 years, range $17-68$ years), all of whom were outpatients. The diabetic patients were screened for clinical microvascular complications by experienced diabetologists. Diabetic subjects with clinical macrovascular disease were excluded from the study. Dilated fundi were examined by an ophthalmoscope and retinopathy was recorded as absent, background or proliferative. The latter category included patients who had undergone previous laser photocoagulation therapy. All subjects were screened for evidence of early diabetic nephropathy by testing urine for albustix-positive proteinuria, measurement of serum creatinine and screening for microalbuminuria in an early morning urine specimen using an in-house immunoturbidometric method (interbatch coefficient of variation (CV) $5.9 \%$ at a level of $\left.46 \mathrm{mg} \cdot 1^{-1}\right)$. Microalbuminuria was defined as $20-200 \mathrm{mg} \cdot 1^{-1}$ with an albumin/creatinine ratio (ACR) greater than $2.5 \mathrm{mg} \cdot \mathrm{mmol}^{-1}$. Proteinuria was defined as greater than $200 \mathrm{mg} \cdot \mathrm{l}^{-1}$ with ACR greater than $2.5 \mathrm{mg} \cdot \mathrm{mmol}^{-1}$.

A group of 30 of the diabetic subjects (18 male, 12 female; median age 29 years, range 17-55 years; median duration of diabetes 4.5 years, range 1-26 years) did not have retinopathy or nephropathy.

A group of 24 of the diabetic subjects ( 17 male, 7 female; median age 35 years, range $22-68$ years; median duration of diabetes
17 years, range $7-44$ years) had clinical diabetic complications. Seven showed background retinopathy alone. Proliferative retino pathy was observed in 17 patients, of whom three were also microalbuminuric and one was proteinuric.

\section{Control subjects}

The control group comprised 42 age-matched normal healthy nondiabetic subjects ( 22 male, 20 female; median age 31 years, range 18-64 years).

Approval of the protocol was obtained from the District Health Authority ethical committee and informed consent was given by all subjects.

\section{Methods}

Lysosomal enzyme assays. Venous blood was collected, between 09.15 and 09.45 hours in order to minimise any possible effects of diurnal variation, from non-fasting subjects (between 1 and $2 \mathrm{~h}$ postprandially). Previous experiments had shown that recent food ingestion did not affect observed enzyme activities. Blood wascollected in to sodium citrate tubes and stored on ice for $15-45 \mathrm{~min}$, plasma enzyme activities having been shown not to change significantly during storage under these conditions for at least $3 \mathrm{~h}$. Platelet-free plasma was prepared bycentrifugation at $2500 \mathrm{~g}$ for $10 \mathrm{~min}$, for immediate assay of lysosomal enzymes utilising 4-methylumbelliferyl synthetic substrates (Sigma, Poole, Dorset, UK). Incubation was at $37^{\circ} \mathrm{C}$ under the conditions $[10,11]$ given in Table 1 . The reaction was stopped using gly cine/carbonate buffer $\mathrm{pH} 10.0$, and fluorescence measured using a Hitachi F-2000 fluorimeter, excitation $365 \mathrm{~nm}$, emission $448 \mathrm{~nm}$. Intrabatch CVs for enzyme assays were less than $3.0 \%$.

Glycated haemoglobin. $\mathrm{HbA}_{1}$ was measured by a reverse electroendosmosis (in-house) method. Interbatch $\mathrm{CV}$ was $7.0 \%$ at a level of $11.8 \% \mathrm{HbA}_{1}$.

Fructosamine. Serum fructosamine was measured by an in-house modification of a colorimetric method [12]. Interbatch $\mathrm{CV}$ was $6.6 \%$ at a level of $4.2 \mathrm{mmol} \cdot 1^{-1}$.

Glucose. Plasma glucose was measured by an automated glucose oxidase/p-aminophenazone method (Bochringer Mannheim, Mannheim, FRG). Interbatch CV was $2.1 \%$ at a level of $12.5 \mathrm{mmol} \cdot \mathrm{l}^{-1}$.

\section{Statistical analysis}

All tabulated results are expressed as median (interquartile range). The significance of differences between subject groups was evaluated by the Mann-Whitney test. Correlations between parameters of glycaemiccontrol and enzyme activities were examined using SpearmanRank analysis. In all tests a significancelevel of $p<0.05$ was applied.

\section{Results}

Plasma lysosomal enzyme activities in diabetic and control subjects are shown in Figure 1. Four of the enzymes, namely $\beta$-D-glucuronidase, $\beta$-D-Nacetylglucosaminidase, $\alpha$-D-mannosidase, and $\beta$-D-galactosidase, showed significant $(p<0.05)$ increases in the diabetic group. However, activities of the remaining three enzymes examined were similar in the diabetic and control subjects. Figure 2 gives an indication of the quality of glycaemic control in the diabetic patients.

Table 2 compares diabetic subjects with and without evidence of clinical complications. None of the lysosomal 

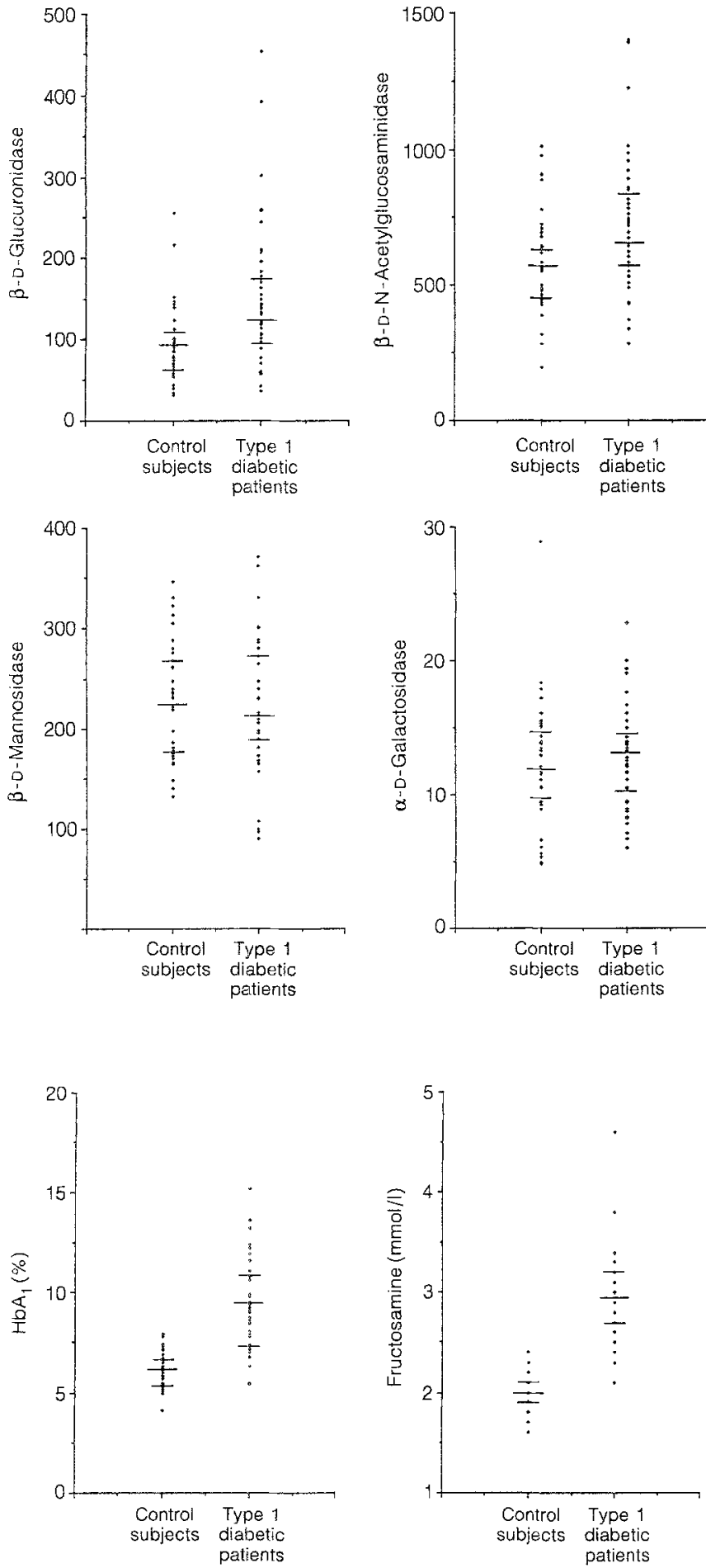

enzyme activities differed significantly between these two groups. Table 2 also shows that parameters of glycaemic control were similar in the two groups of diabetic patients.

Two lysosomal enzymes demonstrated highly significant relationships to parameters of glycaemic control in the diabetic subjects: correlations of $\beta$-D-Nacetylglucosaminidase and $\beta$-D-glucuronidase with $\mathrm{HbA}_{1}$, fructosamine and simultaneous plasma glucose are summarised
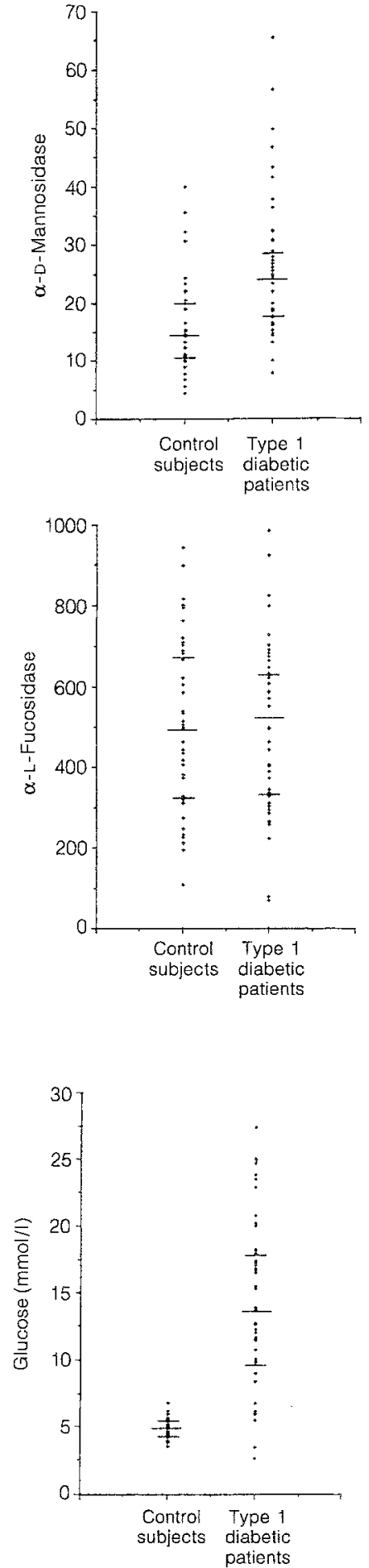

Fig. 2. Parameters of glycaemic control in Type 1 (insulin-dependent) diabetic patients vs control subjects Bars indicate inedian and upper and lower quartile values. Groups differ significantly for $\mathrm{HbA}_{3}$, glucose and fructosamine $(p<0.001)$ in Table 3. None of the other lysosomal enzyme activities correlated significantly $(p<0.05)$ with parameters of glycaemic control.

\section{Discussion}

We have examined a profile of lysosomal glycosidases and have demonstrated an increase in plasma levels of certain enzymes in Type 1 diabetic subjects. Enzyme activities 
Table 3. Correlations $\left(r_{s}\right)$ between plasma lysosomal enzyme activities and glycaemic control in Type 1 (insulin-dependent) diabetic subjects

\begin{tabular}{lllr}
\hline & & $r_{\mathrm{s}}$ & \multicolumn{1}{c}{$p$} \\
\hline$\beta$-D-glucutonidase & $\mathrm{HbA}_{1}$ & 0.56 & $<0.001$ \\
& Fructosamine & 0.38 & 0.004 \\
& Glucose & 0.36 & 0.008 \\
$\beta$-D-Nacetyl- & HbA $_{\mathrm{I}}$ & 0.56 & $<0.001$ \\
glucosaminidase & Fructosamine & 0.50 & $<0.001$ \\
& Glucose & 0.36 & 0.007 \\
\hline
\end{tabular}

were similar regardless of the presence or absence of clinically evident diabetic complications, but were related to the quality of glycaemic control.

Previous studies have produced conflicting data on circulating lysosomal enzymes in diabetes [7]. This has been largely due to the use of serum, in which activities are grossly exaggerated due to in vitro enzyme release from platelets [8]. The assay of fresh, platelet-free plasma in the present study provides a more reliable indication of the in vivo circulating enzyme levels. Also, earlier studies have usually measured only one or two enzymes, notably $\beta$-DNacetylglucosaminidase as this has been regarded as a possible marker of renal damage. In the present study the assay of a profile of seven glycosidase activities has enabled a more detailed examination of abnormal lysosomal function in diabetes.

An overall elevation of serum lysosomal enzymes observed in another study was attributed to a generalised lysosomal activation [13]. Our data on plasma lysosomal enzymes suggest instead that more specific mechanisms are responsible for the increases in certain lysosomal glycosidases, unless our results showing no significant increase in three enzymes are a result of a type II error. An alternative hypothesis is that increased circulating lysosomal enzyme activities in diabetes might arise simply by enzyme loss from damaged tissues [7]. However, we did not observe a further significant increase in enzyme activities due to the presence of clinical diabetic complications, although we cannot exclude the possibility of a type II error. Nor can we exclude the possibility that the enzyme increases in the diabetic subjects with no clinically evident complications are, at least in part, secondary to early covert complications.

We have demonstrated significant positive relationships between plasma enzyme levels and glycaemic control, implying that hyperglycaemia (or possibly insulin deficiency) is a major cause of lysosomal enzyme increases in diabetic patients. It is widely accepted that poor glycaemic control is a major risk factor for development of diabetic complications $[14,15]$. Hyperglycaemia-induced increases in certain lysosomal enzymes may therefore be implicated in the pathogenesis of complications; the degradative action of these enzymes on endothelium leading to abnormalities in the composition of membrane glycoconjugates. Such abnormalities occur in diabetes $[5,16]$ and are believed to reduce membrane charge density, thus causing increased permeability which is a characteristic feature of microangiopathy. Moreover, the carbohydrate side chains of membrane glycoconjugates are implicated in the protection of endothelium from damage by leucocyte-derived proteases [3]. In animal models enzymatic removal of the terminal acidic sugars from arterial endothelium causes increased uptake of low density lipoprotein and fibrinogen [17], thereby accelerating the development of atheroma.

The sources of these circulating enzymes remain to be defined; however, circulating leucocytes or platelets or both represent likely candidates for mediators of the observed increases. Poor glycaemic control is known to profoundly disturb the functions of circulating leucocytes [18] and also leads to abnormal physical properties such as decreased surface charge [19], tending to increase leucocyte interaction with other circulating cells and with vascular endothelium [20]. Leucocyte activation, which would occur under these circumstances, is reportedly accompanied by increased synthesis of $\beta$-D-glucuronidase [21] and some other lysosomal enzymes $[2,22]$. Secretion of lysosomal enzymes from leucocytes into plasma occurs by known physiological processes [4].

Susceptibility to diabetic complications appears to be determined not only by glycaemic control but also by various immunogenetic factors, notably HLA polymorphisms [23]. It is feasible also that the increases in certain lysosomal enzymes in diabetes are directly related to genetic traits. It is well-known that circulating $\alpha$-L-fucosidase levels in the general population are heavily influenced by a genetic polymorphism [24]. Activities of other lysosomal enzymes may also be modified by similar heritable factors. The intriguing possibility of a linkage between genes determining enzyme activities and those affecting susceptibility to Type 1 diabetes and its associated complications deserves consideration.

We have described increases in certain lysosomal glycosidases in the plasma of Type 1 diabetic patients which may represent a link between hyperglycaemia and the development of diabetic complications. The mechanisms mediating these enzyme increases have not yet been fully elucidated and require further attention. The significance of lysosomal enzymes in the pathogenesis of diabetic complications should be evaluated by longitudinal studies.

Acknowledgements. The technical assistance of Ms. J.Morgan is gratefully acknowledged. The authors also wish to thank staff of the Outpatient Pathology Department and Diabetic Clinic, Bristol Royal Infirmary, for their help in ensuring fresh sample collection. P.W. was supported financially by a grant from Diabetes Research in Bristol.

\section{References}

1. Pennock CA (1987) Lysosomal storage disorders. In: Holton JB (ed) The inherited metabolic diseases. Churchill Livingstone, London, pp 59-95

2. Naparstek V, Cohen IR, Fuks Z, Vlodavsky I (1984) Activated T lymphocytes produce a matrix-degrading heparan sulphate endoglycosidase. Nature 310: 241-243

3. Gorog P, Pearson JD (1985) Sialic acid moieties on surface glycoproteins protect endothelial cells from proteolytic damage. J Pathol 146: 205-212 
4. Sabatini DD, Adesnik MB (1989) The biogenesis of lysosomes. In: Scriver CR, Beaudet AL, Sly WS, Valle D (eds) The metabolic basis of inherited disease, 6th edn. McGraw Hill, New York London, pp 200-205

5. Cohen-Forterre L, Andre J, Mozere G, Peyroux J, Sternberg M (1990) Kidney sialidase and sialyltransferase activities in spontaneously and experimentally diabetic rats. Biochem Pharmacol 40:507-513

6. Brown DM, Charonis AS, Furcht LT et al. (1991) An overview of role of matrix components. Diabetes Care 14:157-159

7. Kelly L, Woodward SH (1988) Alterations in the activities of lysosomal glycosidases in human diabetes. Med Sci Res 16: 491-496

8. Lombardo A, Caimi L, Marchesini S, Goi G, Tettamanti G (1980) Enzymes of lysosomal origin in human plasma and serum: assay conditions and parameters affecting the assay. Clin Chim Acta 108: 337-346

9. Colwell JA, Winocour PD, Halushka PV (1983) Do platelets have anything to do with diabetic microvascular disease? Diabetes 32 [Suppl 2]: 14-19

10. Barnes ID (1978) Enzyme abnormalities in bone dysplasias, doctoral thesis. University of Bristol, Bristol, pp 115-169

11. Cooper A, Hatton C, Sardharwalla IB (1987) Acid $\beta$-mannosidase of human plasma: influence of age and sex on enzyme activity. J Inher Metab Dis 10: 229-233

12. Lloyd D, Marples J (1984) Simple colorimetry of glycated serum protein in a centrifugal analyser. Clin Chem 30: 1686-1688

13. Goi G, Fabi A, Lorenzi R et al. (1986) Serum enzymes of lysosomal origin as indicators of the metabolic control in diabetes: comparison with glycated hemoglobin and albumin. Acta Diabetol Lat 23: $117-125$

14. Pirart J (1978) Diabetes mellitus and its degenerative complications: a prospective study of 4400 patients observed between 1947 and 1973. Diabetes Care 1: 168-188, 252-263

15. Tchobroutsky G (1978) Relation of diabetic control to development of microvascular complications. Diabetologia 15: 143152

16. Olgemöller B, Schwaabe S, Gerbitz KD, Schleicher ED (1991) Elevated glucose decreases the content of a basement membrane associated heparan sulphate proteoglycan in proliferating cultured porcine mesangial cells. Diabetologia 35:183-186

17. Gorog P, Born GVR (1982) Increased uptake of circulating lowdensity lipoproteins and fibrinogen by arterial walls after removal of sialic acids from their endothelial surface. Br J Exp Pathol 63: $447-451$

18. Rayfield EJ, Ault MJ, Keusch GT, Brothers MJ, Nechemias C, Smith H (1982) Infection and diabetes: the case for glucose control. Am J Med 72: 439-450

19. Vanhaeverbeek M, Brohee D, Piro P, Lefevre A, Kennes B, Neve $\mathrm{P}$ (1991) Mononuclear cells surface charge properties in diabetes and their relationship with glycation. Diabetologia 34 [Suppl 2]: A 7 (Abstract)

20. Belch JJF (1990) The white blood cell as a risk factor for thrombotic vascular disease. Vasc Med Rev 1: 203-213

21. Olsen I, Bou-Gharios G, Abraham D (1990) The activation of resting lymphocytes is accompanied by the biogenesis of lysosomal organelles. Eur J Immunol 20: 2161-2170

22. Landolfi NF, Leone J, Womak JE, Cook RG (1985) Activation of $\mathrm{T}$ lymphocytes results in an increase in $\mathrm{H}$-2-encoded neuraminidase. Immunogenetics 22: 159-167

23. Mijovic C, Barnett AH (1987) Immunogenetics of diabetic microangiopathy. In: Barnett AH (ed) Immunogenetics of insulin-dependent diabetes. MTP Press, Lancaster, pp 111-120

24. DiCioccio A, Barlow J, Matta K (1986) Specific activity of $\alpha$-Lfucosidase in sera with phenotypes of either low, intermediate or high total enzyme activity and in a fucosidosis serum. Biochem Genet 24: 115-130

Received: 16 April 1992

and in revised form: 12 June 1992

Ms. P.J.Waters

Chemical Pathology Department

St. Michael's Hospital

Southwell Street

Bristol BS2 8EG

UK 